\title{
ДІЯЛЬНІСТЬ ВІДОМЧИХ ІНДУСТРІАЛЬНИХ ПОЖЕЖНИХ КОМАНД В УСРР НАПРИКІНЦІ 1920-х рp. - ПЕРШІЙ ПОЛОВИНІ 1930-х pp.
}

Анотація: У статті розглядаються загальні питання діяльності відомчих індустріальних пожежних команд наприкіниі 1920-х - у першій половині 1930-х років. Аналізуються малодосліджені та недосліджені питання роботи Вищої ради народного господарства (ВРНГ) та Пожежно-страхової інспекиії (ПСІ) у галузі контролю за станом пожежної безпеки на промислових підприємствах, організація та діяльність пожежних команд на підприємствах Української Соціалістичної Радянської Республіки (УСРР), їх структура та фінансування. Також у статті досліджуються питання роботи добровільних промислових вогнеборчих команд, які існували на українських підприємствах у досліджуваний період.

Зроблено висновок, що незважаючи на певні проблеми у пожежній галузі в промисловості у досліджуваний період, відомчі індустріальні пожежні команди, як професійні, так і добровольчі, добре справлялися з вогняною небезпекою, велику роль в управлінні боротьбою з пожежами мала також Пожежно-страхова інспекщіг Вищої ради народного господарства УСРР.

Ключові слова: УСРР, Пожежно-страхова інспекція, промисловість, пожежа, відомчі індустріальні пожежні команди, пожежний караул, пожежна охорона, добровільні промислові пожежні команди

Сучасна українська історична наука на сучасному етапі свого розвитку, на жаль оминає своєю увагою дослідження питань історії пожежної охорони в Україні. Хоча актуальність вивчення цих проблем є, на наш погляд, безумовною. Дослідження проблем пожежної охорони в УСРР в історичній ретроспективі, у тому числі питань розвитку промислових вогнеборчих команд, $є$ досить актуальним, оскільки дає можливість висвітлити нерозроблену у вітчизняній історичній науці проблему. Потреба визначити особливості діяльності відомчих промислових пожежних колективів в УСРР наприкінці 1920-х першій половині 1930-х років зумовлює актуальність нашої праці. Науково-теоретична значимість роботи пояснюється тим, що вона сприяє заповненню історичних лакун у галузі

\footnotetext{
* Харламов Михайло Іванович - доктор історичних наук, доцент, доцент кафедри соціальних і гуманітарних дисциплін Національного університету цивільного захисту України (Харків, Україна);

ORCID: https://orcid.org/0000-0002-5289-0290; e-mail: mike1982kharlamov@gmail.com

Цибулько Ольга Сергіївна - доктор педагогічних наук, доцент, доцент кафедри філософії та соціології Маріупольського державного університету (Маріуполь, Донецька область, Україна); ORCID: https://orcid.org/0000-0003-1297-5465; e-mail: ostsybulko@gmail.com

Гонтаренко Людмила Олександрівна - кандидат психологічних наук, доцент, доцент кафедри соціальних і гуманітарних дисциплін Національного університету цивільного захисту України (Харків, Україна); ORCID: https://orcid.org/0000-0001-6993-5494; e-mail: lgontarenk0910@gmail.com
} 
історії вітчизняної пожежної охорони, відкриває новий світ героїчного минулого вітчизняних вогнеборців, що працювали в промисловості України у вказаний історичний період для широкого наукового загалу. Практична значимість дослідження пов'язана 3 можливим використанням певного досвіду вогнеборчої боротьби українських пожежних у промисловості в сучасній системі пожежної безпеки Державної служби України 3 надзвичайних ситуацій в умовах реформування.

Необхідно зауважити, що дослідження питань діяльності відомчих індустріальних пожежних команд на промислових підприємствах УСРР наприкінці 1920-х - у другій половині 1930-х років є темою, що майже не розглядалася вітчизняними та закордонними істориками. Звернення нашої уваги до цієї теми спонукало майже абсолютне невисвітлення зазначених питань в українській і закордонній історіографії. Частково окремі аспекти нашої роботи розглядалися у публікації черкаського дослідника історії пожежної охорони А.Г. Томіленка ${ }^{1}$, а також у статті М.I. Харламова².

Метою статті $\epsilon$ дослідження особливостей діяльності відомчих індустріальних пожежних команд в УСРР наприкінці 1920-х рр. - першій половині 1930-х рр. Для досягнення зазначеної мети необхідно вирішити такі головні науково-дослідні завдання: схарактеризувати роль і значення Пожежно-страхової інспекції Вищої ради народного господарства УСРР у розвитку промислової пожежної охорони та відомчих індустріальних пожежних колективів УСРР у зазначений історичний період; проаналізувати особливості структури та діяльності професійних промислових вогнеборчих команд і пожежних караулів в УСРР наприкінці 1920-х - першій половині 1930-х років; дослідити специфіку вогнеборчої боротьби добровільних промислових команд пожежних в УСРР у досліджуваний період.

У міських регіонах УСРР/УРСР у міжвоєнний період, окрім професійних комунальних пожежних команд, існували також вогнеборчі організації, що безпосередньо підпорядковувалися не Народному комісаріату внутрішніх справ УСРР (НКВС УСРР) та Народному комісаріату комунального господарства УСРР (НККГ УСРР), а іншим відомствам, зокрема промисловому. У досліджуваний період найбільше уваги приділялося розвиткові промислової пожежної охорони, що було спричинене політикою індустріалізації в країні.

Однією з головних віх у протипожежній охороні промисловості УСРР стало створення при ВРНГ УСРР у лютому 1928 р. пожежно-страхової інспекції. Вона займалася управлінням протипожежною справою в індустрії, у тому числі відповідала за діяльність промислових пожежних команд і дружин. До появи цього державного пожежного органу індустріальні підприємства української республіки подекуди не мали належної охорони власного майна від пожеж, у багатьох випадках вогнеборчі команди заводів і фабрик перебували під керівництвом людей, малокомпетентних у пожежній сфері. Місцеві органи пожежного профілю проводили перевірки стану дотримання правил безпеки на підприємствах нерегулярно та, подекуди, неякісно. Все це негативним чином впливало на

\footnotetext{
${ }^{1}$ Томіленко А.Г. Становлення та розвиток пожежної охорони на об'єктах промисловості України у міжвоєнний період // Гуманітарний вісник. 2017. № 27 (11). С. 28-37.

${ }^{2}$ Харламов M.I. Діяльність пожежних інспекторів та завідувачів пожежною охороною (брандмейстерів) промислових підприємств у 1927-1930-х роках в Україні // Гілея: науковий вісник. 2018. № 131 (4). С. 58-60.
} 
пожежну охорону як індустріальних об'єктів, так і міст у цілому, та призводило до великих матеріальних збитків через пожежі.

Для здійснення вогнеборчих функцій Пожежно-страховою інспекцією на місцях, наказом ВРНГ влітку 1928 р. було створено при місцевих радах народного господарства i правліннях трестів та об’єднань спеціальні підрозділи з протипожежної безпеки. Однак їх формування затягнулося у деяких містах на достатньо довгий термін після оголошення наказу. Одні начальники не бачили потреби у створенні будь-яких додаткових органів 3 попередження вогняної небезпеки, інші - не зовсім розуміли значення цієї справи для забезпечення протипожежного захисту підприємств. Часто при утворенні структурних підрозділів із протипожежної охорони необхідні були суттєві фінансові витрати, що було не до смаку окремим заводам і трестам. На ПСІ покладалися такі суттєві обов'язки: 1. Видання наказів, циркулярів, інструкцій стосовно пожежної охорони. 2. Контроль за станом протипожежного захисту заводів та фабрик та розвитком пожежної справи в місцевих органах ВРНГ. 3. Надання актів обстеження після оглядів об'єктів промисловості щодо протипожежної безпеки. Разом із зазначеним, інспекція розглядала проекти та давала висновки щодо необхідності обладнання підприємств протипожежною сигналізацією, протипожежним водогоном, засобами пожежогасіння, спринклерами і так далі ${ }^{3}$. Пожежнострахова інспекція займалася організацією та контролем діяльності пожежних інспекторів і промислових пожежних команд і дружин.

Для охорони будівель і майна від пожеж на промислових підприємствах існували окремі вогнеборчі організації під контролем і доглядом пожежних інспекторів. До них відносилися: професійні промислові вогнеборчі команди, у складі шістьох і більше осіб на зміну та пожежні караули (пости), у складі від одного до шести чоловік на зміну, а також добровільні пожежні дружини. Вони створювалися за згодою з місцевими органами державного пожежного нагляду та вищими органами пожежної охорони української індустрії в залежності від певних умов. Умови створення пожежних організацій залежали від масштабу території, що охоронялася, значущості та важливості виробництва та споруд, ступеня їх вогненебезпечності; від стану та придатності водоперегоних мереж, штучних і природних водоймищ. А також від необхідності обслуговування сусідніх підприємств і можливості виїзду для надання допомоги у міста та від наявності поруч професійної чи добровільної пожежної команди ${ }^{4}$.

Професійною промисловою пожежною командою називалася організація вогнеборців, що у складі лише однієї чергової зміни мала змогу прибути до місця пожежі з необхідним пожежним обладнанням і дати не менше двох струменів води від водопроводу й одного струменя від ручної труби з одночасним встановленням пожежної драбини. Пожежніпрофесіонали фабрик і заводів не працювали на виробництві, а займалися суто вогнеборчою справою. Професійні команди обов'язково створювалися на підприємствах 3 площею забудови більше одного квадратного кілометра, або на заводах 3 кількістю робітників і службовців білыше ніж 750 осіб. Також професійними вогнеборцями

\footnotetext{
${ }^{3}$ Томіленко А.Г. Становлення та розвиток пожежної охорони... С. 30.

${ }^{4}$ Документы об организации пожарных дружин и выполнении правил противопожарной безопасности на промышленных предприятиях РСФСР и УССР // Центральний держархів вищих органів влади та управління України (ЦДАВО України). Ф. 34. Оп. 13. Спр. 645. Арк. 33.
} 
забезпечувалися промислові установи 3 особливо вогненебезпечним виробництвом ${ }^{5} 3$ 1930 р. професійні пожежні команди промисловості стали воєнізованими, тобто діяли за статутами РСЧА.

На пожежні команди професіоналів покладалося: гасіння пожеж 3 терміновим повідомленням про це найближчої міської пожежної частини; утримання у справності та належній готовності усіх засобів пожежогасіння, приладдя та пожежного інвентарю; несення постової служби в особливо небезпечних місцях; обхід підприємства для вжиття належних заходів попередження виникнення пожеж. А також несення постової служби у театрах, клубах та інших місцях скупчення людей, розташованих на території підприємства; прибирання усіх приміщень, що належали пожежній команді та прилеглої території; надання допомоги у випадку стихійних лих. Інші роботи, не пов'язані 3 пожежною охороною, не могли бути покладені на співробітників вогнеборчих колективів. Район дії пожежної команди визначався кордонами підприємства та сусідніми територіями. У випадку, якщо пожежа поруч загрожувала самому заводу чи фабриці, виїзд пожежних за межі промислової одиниці допускався, якщо на території залишався бойовий вогнеборчий підрозділ. Район і порядок виїзду промислових пожежних за межі своєї зони відповідальності визначався місцевим управлінням пожежної охорони ${ }^{6}$.

Керівник пожежної промислової команди - брандмейстер керував безпосереднім гасінням пожежі, ніхто з адміністрації установи не мав права втручатися у його роботу ${ }^{7}$ При спільних діях «промисловців» 3 міською пожежною командою головував начальник «містян». У випадку гасіння пожежі разом 3 добровільними дружинами - головним був брандмейстер промислової команди. Він же інструктував своїх підлеглих і проводив навчальні тривоги 3 відома адміністрації; слідкував за справним станом усіх засобів вогнегасіння, пожежного устаткування й інвентарю; визначав розташування пожежних постів; здійснював розподіл робіт між пожежними; слідкував за дотриманням чистоти у пожежних приміщеннях; контролював дотримання робітниками та службовцями правил пожежної безпеки на території підприємства. У багатьох випадках брандмейстер виконував функції завідувача з пожежної охорони підприємства, як це було, наприклад, на окремих підприємствах Харкова 8 .

За тимчасової відсутності брандмейстера його підміняв заступник або старший пожежної зміни. Начальник професійної пожежної команди промислового підприємства звітував перед завідувачем пожежною охороною (якщо він сам не виконував обов'язки останнього) та перед керівництвом заводу чи фабрики. Обов'язки пожежних за певними посадами визначалися інструкцією про внутрішню службу у професійних командах на території УСРР. Пожежні команди повинні були бути оснащені усім необхідним пожежним приладдям, а також спеціальним і виробничим одягом згідно норм забезпечення, що були встановлені Наркоматом праці УСРР. Комплектування профкоманд відбувалося

\footnotetext{
${ }^{5}$ Материалы о состоянии пожарной охраны на территории УССР // ЦДАВО України. Ф. 5. Оп. 3. Спр. 1428. Арк. 1зв.

${ }^{6}$ Ibidem.

${ }^{7}$ Харламов М.I. Діяльність пожежних інспекторів та завідувачів... С. 59.

${ }^{8}$ Материалы о состоянии пожарной охраны на территории УССР // ЦДАВО України. Ф. 5. Оп. 3. Спр. 1428. Арк. 2.
} 
безпосередньо підприємствами у встановленому порядку з осіб спеціальної пожежної кваліфікації. Переведення звичайних робітників заводу на посаду пожежного відбувалося винятково 3 дозволу місцевих органів державного пожежного контролю. Про усі зміни у складі команд професійних пожежних підприємств необхідно було повідомляти до управлінських пожежних організацій9

Місцеві державні пожежні органи суттєво впливали на роботу промислових пожежних колективів. Вони контролювали загальний професійний стан команд, їх підготовку, технічне спорядження й оснащення. Пожежні «ревізори» проводили контрольні та навчальні тривоги у будь-який час з відома керівництва підприємств, здійснювали огляд приміщень, спорядження, реманенту команд і всього протипожежного обладнання установ. Також могли змінювати порядок виконання внутрішньої служби промислових пожежних і могли ініціювати зняття 3 посад брандмейстерів, їх помічників або окремих пожежних, якщо останні не відповідали своєю підготовкою займаній посаді. Усі дії (тривоги, огляди), що здійснювалися контролерами з управління пожежної охорони міста, а також зауваження стосовно рівня пожежної безпеки на виробництві заносилися у спеціальні книги, які зберігалися на підприємстві ${ }^{10}$.

До 1932 р. професійні команди промисловості в УСРР могли мати різні посадові штатні одиниці. 3 метою білышої організованості у цій сфері з 1932 р. в індустріальних професійних вогнеборчих колективах створювалася єдина система посад, що була закріплена інструкцією 3 визначення штатів професійних пожежних команд на підприємствах наркоматів легкої та важкої промисловості УСРР. До складу профкоманд пожежних могли входити: начальник промислової пожежної команди (ППК), помічник начальника ППК 3 політичної роботи (політрук), помічник начальника ППК, старший пожежної зміни, старші пожежні, діловоди, монтер електросигналізації, шофери, мотористи, гринельник (спеціаліст зі спринклерного устаткування), телефоністи, візники, рядові пожежні бойового розрахунку, рядові постової служби ${ }^{11}$.

Посада начальника пожежної команди мала бути на усіх заводах, незалежно від загальної кількості людей у колективі. Помічники начальника вводилися до штату організації, якщо загальна кількість рядових працівників пожохорони була більше 15 осіб. Політруки працювали у командах 3 кількістю від 40 осіб. Старші зміни вводилися до складу ППК, у випадку кількості рядових пожежних від 6 до 15 осіб. Діловод приймався на посаду до команди у кількості від 40 осіб (якщо борців з вогнем було менше, документацію вів один $з$ рядових телефоністів). Монтери сигналізації працювали у ППК, у яких було не менше двох шлейфних стрічкових пожежних сигналізацій типу «Морзе». Шофери вводилися до штату ППК, де малися пожежні автомобілі (по одній особі на авто у службову зміну). Мотористи працювали у дружинах, що мали на озброєнні мотопомпи. Гринельники працювали, зазвичай, на великих підприємствах, де були автоматичні системи пожежогасіння (спринклери). Посади телефоністів були лише у командах з кількістю

\footnotetext{
${ }^{9}$ Материалы о состоянии пожарной охраны на территории УССР // ЦДАВО України. Ф. 5. Оп. 3. Спр. 1428. Арк. 2зв.

${ }^{10}$ Ibidem.

${ }^{11}$ Материалы, циркуляры и переписка с заводами о состоянии противопожарной обороны и противопожарных мероприятиях // ЦДАВО України. Ф. 1218. Оп. 1. Спр. 238. Арк. 66зв.
} 
вогнеборців більше 15 осіб ${ }^{12}$. 3 введенням нової системи у ППК деякі штатні посади, як-то: старший сокирник або старший трубник, ліквідовувалися, пожежні отримували статус рядових, але отримували дещо вищу зарплатню за старими нарахуваннями.

На підприємствах, окрім вогнеборчих команд, діяли також пожежні караули, що складалися $з$ професійних пожежних. Караул не був окремою самостійною бойовою вогнеборчою одиницею. На нього покладалася лише пожежно-вартова служба, тобто спостереження за пожежною охороною окремих ділянок території ${ }^{13}$, утримання у справному стані пожежного приладдя та реманенту на окремих виробництвах, гасіння локальних пожеж спеціальними засобами пожежогасіння. Безпосереднє спостереження за станом пожежних караулів та їх виконанням служби покладалося на завідувача пожежною охороною заводу. 3-поміж пожежних у караулі призначався старший, що контролював службу. Кількість постів, розподіл вогнеборців, що входили до складу караулу, обов'язки постових пожежних визначалися спеціальною інструкцією, що створювалася на підприємстві та затверджувалася органами пожежного нагляду міста ${ }^{14}$.

Утримання пожежного караулу, його спорядження та забезпечення спецодягом i прозодягом здійснювалося за рахунок індустріальної організації згідно норм Народного комісаріату праці УСРР. Як і у випадку 3 професійними командами, комплектування пожежних караулів відбувалося з відома органів державного пожежного нагляду, останні ж здійснювали і спеціальну перевірку постів і рядових пожежних під час несення ними служби.

Разом 3 професійними пожежними командами та караулами, в охороні промисловості брали участь і добровільні пожежні дружини, що діяли на основі затверджених НКВС статутів та інструкцій. Добровільні промислові організації мали на меті безпосередньо боротися $з$ пожежами на території підприємств, вживати заходів із запобігання виникнення займань, доглядати за точним виконанням профілактичних протипожежних правил на території заводу чи фабрики. Для кращого здійснення зазначеної мети дружинники мали займатися практичним і теоретичним вивченням пожежної справи, доглядати за справністю протипожежного устаткування та належним станом різних протипожежних заходів, знати потенційно небезпечні у пожежному відношенні об'єкти підконтрольної зони. Вони допомагали офіційним посадовим особам пожежного нагляду у справі ознайомлення робітників і службовців, які не були задіяні у добровільних пожежних організаціях, з вимогами пожежної безпеки стосовно попередження паніки під час пожеж, важливості дотримання безпечного поводження з вогнем ${ }^{15}$.

Промислова добровільна пожежна дружина після офіційного реєстрування отримувала право мати власний прапор, печатку, що затверджувалося рішенням органів НКВС УСРР, а iї члени могли носити форму встановленого державою зразка. Після цього добровільні пожежі отримували право на пільги від держави. У своїй діяльності пожежні добровольці,

\footnotetext{
${ }^{12}$ Материалы, циркуляры и переписка с заводами о состоянии противопожарной обороны и противопожарных мероприятиях // ЦДАВО України. Ф. 1218. Оп. 1. Спр. 238. Арк. 66зв.

${ }^{13}$ Лаптий А.Ф. Из опыта службы в пожарной охране (рассказы ветерана). Харьков, 1976. С. 23.

${ }^{14}$ Материалы о состоянии пожарной охраны на территории УССР // ЦДАВО України. Ф. 5. Оп. 3. Спр. 1428. Арк. 2зв.

${ }^{15} \mathrm{O}$ регистрации устава добровольных пожарных дружин предприятий Харькова и материалы о их деятельности // Держархів Харківської області (ДАХО). Ф. Р-845. Оп. 2. Спр. 782. Арк. 4.
} 
що працювали на підприємстві, керувалися загальними законоположеннями у протипожежній сфері, а також розпорядженнями свого заводоуправління та органів пожежної охорони. Якщо на підприємстві існувала професійна пожежна команда, то добровольча організація була допоміжним структурним підрозділом, а начальником такої дружини обов'язково був брандмейстер професійної команди ${ }^{16}$.

Членами пожежної дружини могли бути працівники підприємства, які досягли вісімнадцятирічного віку та не мали фізичних недоліків, які могли б перешкоджали праці у пожежній сфері. Чисельний склад команди добровільних вогнеборців визначала адміністрація індустріальної установи за погодженням з місцевими органами державного пожежного нагляду та після затвердження Пожежно-страховою інспекцією ВРНГ УСРР. Кількість пожежних на заводі чи фабриці залежала від декількох факторів: від масштабу підконтрольної території, важливості та ступеня вогненебезпеки конкретних споруд, будівель або майна; від стану та спроможності для пожежогасіння водоперегінних мереж, наявності природних і штучних джерел води; від існуючої необхідності обслуговування у пожежному відношенні сусідніх підприємств і реальної можливості виїзду для надання допомоги; від існування неподалік міцної пожежної професійної чи добровільної команди, яка б могла допомогти у випадку потреби ${ }^{17}$.

При організації команди пожежних добровольців на підприємстві оголошували запис бажаючих працівників, які б хотіли увійти до складу дружини на підставі спеціального статуту, який оголошувався одночасно з повідомленням про запис. Після складення списку осіб претендентів на членство у команді добровольців, усіх їх оглядав лікар, який видавав їм (або не видавав) довідку про відсутність фізичних вад для роботи вогнеборцем ${ }^{18}$. Особи, що бажали вступити до дружини, подавали відповідну заяву начальникові пожежної команди. Прийняття робітника до членів дружини здійснювалося після рішення керівництва підприємства та проводилося спеціальним наказом. Члени пожежної дружини могли вибувати з її складу за розпорядженням адміністрації промислової установи після рапорту начальника пожежних добровольців, або за власним бажанням, подаючи відповідну заяву на ім'я начальника дружини.

За подвиги, що виявляли дружинники під час виконання своїх обов'язків, а також за довголітню пожежну службу та за особливі заслуги у справі зміцнення й розвитку пожежної охорони, члени пожежних добровольчих бригад могли отримувати різні нагороди. До них відносилися: похвальні відзнаки, нагородні жетони, речі пожежного знаряддя, грошова або інша матеріальна допомога, нагороди для пожежних працівників, встановлені НКВС УСРР, загальнодержавні нагороди. Кожне нагородження опубліковувалося в наказі по підприємству. Про нагородження відзнаками НКВС, жетонами та нагородами держави завод чи фабрика клопотали через округові органи державного пожежного нагляду 3 одночасним повідомленням органів пожежної охорони промисловості.

\footnotetext{
${ }^{16}$ Документы об организации пожарных дружин и выполнении правил протовопожарной безопасности на промышленных предприятиях РСФСР и УССР // ЦДАВО України. Ф. 34. Оп. 13. Спр. 645. Арк. 17.

${ }^{17} \mathrm{O}$ регистрации устава добровольных пожарных дружин предприятий Харькова и материалы о их деятельности // ДАХО. Ф. Р-845. Оп. 2. Спр. 782. Арк. 9.

${ }^{18}$ Документы об организации пожарных дружин и выполнении правил протовопожарной безопасности на промышленных предприятиях РСФСР и УССР // ЦДАВО України. Ф. 34. Оп. 13. Спр. 645. Арк. 21.
} 
Керівництво добровольчою командою покладалося на начальника дружини, який мав право призначати керівників окремих загонів. За невиконання розпоряджень своїх начальників під час виконання пожежної служби на членів дружини могли накладатися певні стягнення. Серед них: попередження, догана, виключення зі складу колективу згідно з табелем, затвердженим НКВС УСРР та НКП УСРР. Загальні розпорядження по дружині проводив іï начальник через накази керівництва індустріальної установи. Призначення та звільнення начальника пожежної дружини відбувалося за рішенням адміністративного складу заводу чи фабрики. При цьому усі процедури мали бути заздалегідь погоджені з вищими органами пожежної охорони по лінії промисловості, а також з регіональними органами державного пожежного нагляду. Представники місцевих державних адміністративних органів пожежної охорони могли вимагати від підприємств заміни начальника дружини, у випадку, якщо дана посадова особа визнавалася некомпетентною у пожежній справі ${ }^{19}$.

Усі члени пожежної дружини мали проводити активну роботу у сфері забезпечення пожежної охорони. Вони були повинні негайно за сигналом тривоги з'являтися на місце зборів або пожежі для участі в їі гасінні, мали терміново виконувати накази своїх безпосередніх керівників або осіб що їх заступали, не мали права йти з місця пожежі або навчання без дозволу начальника дружини або загону. Добровільні пожежні мали з'являтися на навчання у призначений час, доглядати за точним і неухильним виконанням заходів запобіжного характеру, доглядати за нормальним станом усього підзвітного вогнегасильного приладдя, про усі порушення мали повідомляти своїм керівникам загонів або начальникові дружини ${ }^{20}$.

Вогнеборці у статусі добровольців стежили за тим, щоб пожежне устаткування не використовувалося на потреби, які не стосувалися пожежної справи. Їм ставилося в обов'язок добре знати статут своєї дружини, інструкції й усі розпорядження, що видавалися наказом по команді. Усі претензії на накази та розпорядження начальника члени дружини могли висловлювати вищому керівництву тільки після повернення 3 пожежі або навчання ${ }^{21}$. Членів дружини за невиконання наказів керівника на місці інциденту, а також своїх службових обов'язків негайно усували 3 пожежі або навчання за розпорядженням начальника дружини, після чого їх у встановленому порядку могли позбавити членства у команді пожежних. Окремі обов'язки членів пожежних добровільних організацій визначалися інструкцією внутрішнього устрою бойової частини добровільних пожежних організацій, що була затверджена НКВС УСРР 22 .

Усі витрати на утримання дружини добровольців покладалися на завод чи фабрику, при яких ця команда була організована. Пожежна команда мала отримати від промислової установи: окреме помешкання з опаленням та освітленням, розташоване на території

\footnotetext{
${ }^{19}$ Документы об организации пожарных дружин и выполнении правил протовопожарной безопасности на промышленных предприятиях РСФСР и УССР // ЦДАВО України. Ф. 34. Оп. 13. Спр. 645. Арк. 18.

${ }^{20} \mathrm{O}$ регистрации устава добровольных пожарных дружин предприятий Харькова и материалы о их деятельности // ДАХО. Ф. Р-845. Оп. 2. Спр. 782. Арк. 5.

${ }^{21}$ Документы об организации пожарных дружин и выполнении правил протовопожарной безопасности на промышленных предприятиях РСФСР и УССР // ЦДАВО України. Ф. 34. Оп. 13. Спр. 645. Арк. 18.

${ }^{22} 0$ регистрации устава добровольных пожарных дружин предприятий Харькова и материалы о их деятельности // ДАХО. Ф. Р-845. Оп. 2. Спр. 782. Арк. 6.
} 
підприємства, для вартування і навчання, а також приміщення для пожежного приладдя й одягу; протипожежне приладдя, знаряддя та різні матеріали у кількості, потрібній для роботи колективу; бойове й інше обмундирування за нормами Наркомату праці УСРР. Начальникові дружини та його помічникові повинні були надавати квартири біля пожежного депо на відстані не далі 320 метрів (150 сажнів). Інші рядові члени добровільної команди одержували квартири від промислових установ на загальних підставах з іншими працівниками заводу. Але при рівних умовах 3 «не-членами» пожежних колективів, дружинники мали переваги при отриманні житла. За час, який пожежні проводили на навчаннях, учбових тривогах, пожежах, караулах, практичному навчанні, підприємство видавало спеціальні винагороди за нормами, встановленими адміністрацією закладу за погодженням з відповідною профспілкою ${ }^{23}$.

У випадку інвалідності або тимчасової непрацездатності через каліцтво, яке трапилося під час гасіння пожеж або навчання чи тривоги, члени пожежних дружин (робітники та службовці підприємства) отримували встановлену допомогу у порядку соціального страхування. Родини робітників - членів пожежних команд, також отримували допомогу у випадку смерті добровольця на пожежі або навчанні. Окрім того, підприємства повинні були страхувати в Укрдержстрахові своїх членів дружин у порядку пільгового страхування на суму 1000 крб., на випадок смерті або інвалідності ${ }^{24}$.

Промислові добровільні пожежні дружини з метою отримання загальногромадських державних пільг, що були закріплені відповідними постановами уряду уСРР, мали здійснити низку дій. Вони повинні були зареєструватися у відповідних державних адміністративних органах і місцевих виконкомах за встановленим порядком. Про факт реєстрації дружини адміністрація підприємства сповіщала вищі органи пожежної охорони по лінії промисловості та місцеві органи державної пожежної охорони. За недоцільне використання пожежних дружин з їх технічним устаткуванням і приладдям, за покладання на них робіт, що не стосувалися галузі пожежної безпеки своєї індустріальної установи, винні притягалися до відповідальності згідно діючого на той момент законодавства ${ }^{25}$.

Звітність і діловодство по дружині мав вести її начальник за формами, встановленими адміністрацією закладу. Витрати на команду проводилися за домовленостями 3 керівництвом, а всією канцелярською роботою дружинників завідував апарат підприємства під керівництвом голови пожежної команди. Вогнеборча дружина добровольців могла бути розпущена за рішенням адміністрації заводу після попереднього погодження з державними пожежними органами та пожежним керівництвом ВРНГ УСРР.

Таким чином, у 1928-1934 pр. в УСРР була створена система пожежної охорони промисловості, в якій провідне місце займала Пожежно-страхова інспекція ВРНГ. Їй підпорядковувалася пожежна інспекція трестів і місцевих органів ВРНГ, а далі йшли брандмейстери та завідувачі пожежними частинами підприємств, які очолювали команди промислових вогнеборців, як професійних, так і добровільних. Завідувачі пожежною

\footnotetext{
${ }^{23}$ Документы об организации пожарных дружин и выполнении правил протовопожарной безопасности на промышленных предприятиях РСФСР и УССР // ЦДАВО України. Ф. 34. Оп. 13. Спр. 645. Арк. 19.

${ }^{24}$ Ibid. Арк. 22.

${ }^{25} \mathrm{O}$ регистрации устава добровольных пожарных дружин предприятий Харькова и материалы о их деятельности // ДАХО. Ф. Р-845. Оп. 2. Спр. 782. Арк. 10.
} 
охороною та брандмейстери безпосередньо наглядали за виконанням протипожежних правил на індустріальних об'єктах, готували робітників і пожежних працівників до спеціальних умов при гасінні пожеж, наглядали за станом протипожежного обладнання та устаткування. Не дивлячись на добрі результати роботи Пожежно-страхової інспекції, досить часто виникали і проблеми. Нерідко накази ПСІ місцевим органам ВРНГ, керівникам установ і заводоуправлінь не виконувалися, особливо якщо необхідно було виділяти кошти на заходи протипожежної безпеки ${ }^{26}$. Підприємства прагнули до зменшення собівартості продукції, тож спеціальні видатки на протипожежну безпеку викликали опір у начальників індустріальних установ. Ліквідація Наркомату внутрішніх справ УСРР на початку 1930-х років сприяла концентрації пожежної охорони промисловості саме у системі Вищої ради народного господарства, а не у Наркоматі комунального господарства УСРP.

У 1934 р. усі промислові пожежні команди вогнеборців мали потрібні засоби пожежогасіння у відповідністю з масштабом і характером виробництва на заводі чи фабриці. Найбільш крупні підприємства мали на озброєнні пожежних команд автонасоси та мотопомпи, будувалися спеціальні пожежні депо при заводах. Усі індустріальні заклади забезпечувалися протипожежним водопостачанням, пожежними водогонами, насосами та спринклерними установками, якщо це було потрібно. В СРСР у цей період припинили імпорт вогнетривкої цегли, будувалися спеціальні заводи з виробництва вітчизняних вогнетривких матеріалів. Таким чином, заходи, вжиті ВРНГ УСРР щодо поліпшення системи захисту від пожеж підприємств, у цілому дали хороші результати. Серед проблем, які впливали на протипожежний захист промислових об’єктів у 1928-1934 роках, однією 3 найбільш вагомих була невідповідність техніки пожежної безпеки темпам індустріалізації. Перед вогнеборцями з'явилися нові завдання, над якими практично не доводилося працювати раніше. Серед них, наприклад, робота на висотних спорудах, кількість яких суттєво збільшилася, ліквідація пожеж на водних електростанціях та аеродромах тощо. Всі згадані об’єкти вимагали новаторських способів пожежогасіння.

\section{Mykhailo Kharlamov, Olha Tsybulko, Liudmyla Gontarenko}

\section{Activities of Departmental Industrial Fire Brigades in the UkrSSR in the Late 1920s - the First Half of the 1930s}

Abstract: The article considers general issues of departmental industrial fire brigades in the late 1920s - in the first half of the 1930s. The little-studied and unexplored issues of work of the Supreme Economic Council (SEC) and the Fire Insurance Inspectorate (FII) in the field of fire safety control at industrial enterprises, organization and activity of fire brigades at the enterprises of the Ukrainian Socialist Soviet Republic (UkrSSR), their structure and financing. The article also examines the work of voluntary industrial firefighting teams that existed at Ukrainian enterprises in the study period. It is concluded that despite certain problems in the fire industry in the industry during the study period, departmental industrial fire brigades,

\footnotetext{
${ }^{26}$ Томіленко А.Г. Становлення та розвиток пожежної охорони... С. 28-37.
} 
both professional and volunteer, coped well with the fire hazard, played a major role in fire control and fire inspection of the SEC of the USSR. In 1928-1934, a system of fire protection of industry was created in the UkrSSR, in which the leading place was occupied by the Fire and Insurance Inspectorate of the Supreme Economic Council. The fire inspection of trusts and local bodies of the Supreme Economic Council was subordinated to it, followed by fire chiefs and heads of fire brigades of enterprises, which led teams of industrial firefighters, both professional and voluntary. Fire chiefs and fire chiefs directly supervised the implementation of fire regulations at industrial facilities, prepared workers and firefighters for special conditions in extinguishing fires, and monitored the condition of fire-fighting equipment and facilities. Despite the good results of the Fire and Insurance Inspectorate, problems often arose. FFI orders to local SEC bodies, heads of institutions and plant administrations were often not carried out, especially if it was necessary to allocate funds for fire safety measures. Enterprises sought to reduce the cost of production, so special expenditures on fire safety were opposed by the heads of industrial institutions. The liquidation of the People's Commissariat of Internal Affairs of the UkrSSR in the early 1930s contributed to the concentration of fire protection of industry in the system of the SEC, and not in the People's Commissariat of Public Utilities of the UkrSSR.

Keywords: Ukrainian SSR, Fire and Insurance Inspectorate, industry, fire, departmental industrial fire brigades, fire guard, fire protection, voluntary industrial fire brigades 